\title{
閉鎖性領域内の海水交換特性
}

\section{Characteristics of Sea Water Exchange in Semi-Enclosed Areas}

\author{
高山知司*、吉岡洋 $* *$ 、大栗㓮 $* * *$ \\ Tomotsuka Takayama, Hiroshi Yoshioka, Tsuyoshi Oguri
}

\begin{abstract}
Characteristics of sea water exchange between a semi-enclosed area (narrow channel or harbor) and its outer region in coastal sea was investigated by a numerical simulation. The flow was calculated with nonlinear baroclinic two layers model and mixing process was analyzed with water particle trajectories. Distribution of water residence time and variation of exchange ratio were evaluated. Dominant horizontal oscillating flow had little effect for water exchange. Therefore, residual flow including vertical component played on important role for it. Small jetty type structures which disturb the dominant oscillating flow at a mouth of harbor change the residual flow pattern and make remarkable effect on water exchange.

Keywords: water exchange, residual flow, residence time, tidal mixing
\end{abstract}

\section{1.はじぬに}

我が国の沿岸海域では、東京湾横断道路,関西国際空港 2 期事業および中部新国際空港などが建設または計画 されているように、大規模な開発が続いている。しかし、沿岸海域は居住域に近接して、人間活動の影響を受け 易いため、そこでの水質污染は深刻な社会問題となっている。本研究はその適切な対応策を検討寸るために、閉 鎖性領域の海水交換機構をオイラー・ラグランジェ法（潮流の場を非線型多層モデルで計算し、その場に粒子を おいてラグランジェ的に流れに乗った軌跡を求めて、海水交換を再現する）を用いた数值モデルによって究明す るものである。本計算法は、海峡を通しての海水交換量の決定方法として、今里・淡路らによって開発され、ま ず明石海峡や鳴門海峡に適用されたものであり 11 ２２３）、その後沿岸一外洋交換過程や、大洋のグローバルな海 水交流の研究に適用されて、多くの成果を上げてきた。しかし港湾区域のような小スケールの問題に対しては、 適用例はまだ少なく、現場環境に適合した改良が求められている。そこで、本研究では、沿岸海域において開発 工事によって出現した長水路型や港湾型の閉鎖性領域の海水交換特性について調べている。

\section{2 . 計算方法}

\section{1 地形と境界条件}

潮流計算は、西側のみ開いた閉鎖領域を 2 層 レベルモデル(格子間隔 $40 \mathrm{~m}$ 、縦 $30 \times$ 横 150 格 子、上層 $10 \mathrm{~m}+$ 潮位、下層 $10 \mathrm{~m}$ )で行った。対 象海域は中央の縦 $30 \times$ 横 50 格子内であるが、 そこに安定した潮流の場を作るために両側に縦 $30 \times$ 横 50 格子の訃算領域をとり、西侧の閒境 界に振幅 $37 \mathrm{~cm}$ の $\mathrm{M} 2$ 分潮の水位を強制的に与 え、東端はスリップ境界で自由に反射させて、 定在波的な振動を励起させた。対象領域に島に 挟まれた辰水路や掘り込み港湾地形を設け、陸 地境界ではノンスリップ条件を、その他の境界 ではスリップ条件をちえている。(図ー1)

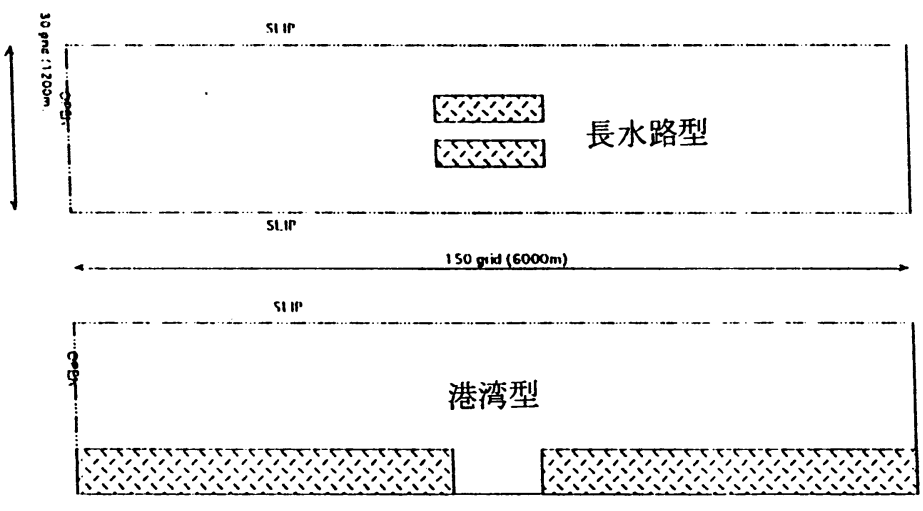

図-1 地形条件およひ境界条件

$* *$

*** 学生会員
京都大学防災研究所水災害研究部門（611-0011 宇治市五ヶ生）

京都大学防災研究所水災害研究部門

京都大学大学院 


\section{2 基礎方程式}

流速場の計算は、タイムステップ 6 秒で上下 2 層それぞれの水平成分 $u$ と鉛直成分 $w$ を次の力程式によって 求めている。

$$
\begin{aligned}
& \frac{\partial \mathbf{u}}{\partial t}+\mathbf{u} \cdot \nabla_{H} \mathbf{u}+w \frac{\partial \mathbf{u}}{\partial z}+\jmath \mathbf{k} \times \mathbf{u}=-\frac{1}{\rho} \nabla_{H} P+v_{H} \nabla \\
& \frac{\partial P}{\partial z}=-\rho g \cdots \cdots(2) \\
& \nabla_{H} \cdot \mathbf{u}+\frac{\partial w}{\partial z}=0 \cdots \cdots(3) \\
& \frac{\partial \rho}{\partial t}+\mathbf{u} \cdot \nabla_{H} \rho+w \frac{\partial \rho}{\partial z}=\mathbf{k}_{H} \nabla^{2}{ }_{H} \rho+\mathbf{k}_{z} \frac{\partial^{2} \rho}{\partial z^{2}} \cdots \cdots(4)
\end{aligned}
$$

式( 1 )は水平方向の運動方程式、式 (2)は鉛直方向 の運動方程式、式(3)は連続式、式(4)は熱·物質の 搪散方程式をそれぞれ表している。P は圧力、 $\boldsymbol{k}$ は鉛 直単位ベクトル、 $\rho$ は海水の密度、 $H$ は水深、 $f=8.2$ $\left.\times 10^{-5} \mathrm{~cm}^{2} \cdot \mathrm{s}^{-1}\right)$ はコリオリパラメータ、 $\nu_{H}=K_{H}\left(=10^{4}\right.$ $\left.\mathrm{cm}^{2} \cdot \mathrm{s}^{-1}\right)$ 次水平渦動粘性係数、, $\nu_{z}=K_{z}\left(=1 \mathrm{~cm}^{2} \cdot \mathrm{s}^{-1}\right)$ は 鉛㨁渦動粘性係数である。

\section{3 粒子追跡計算}

時刻 $t$ 、位置 $X$ における流速 $U(X, t)$ は

$$
\frac{d \mathbf{X}}{d t}=\mathbf{U}(\mathbf{X}, t)
$$

従って、

$$
\mathbf{X}-\mathbf{X}_{0}=\int_{t_{0}}^{t} \mathrm{U}(\mathbf{X}, t) d t
$$

となり,これを 4 次精度の Runge Kutta 法によって 積分すると、ある時刻における粒子位置 $X(t)$ と、任 意の位置、時刻における流速 $U$ がわかれば、時刻 $(t+\Delta t)$ における粒子位㯰 $X(t+\Delta t)$ は、

$$
\mathbf{X}_{(t+\Delta t)}=\mathbf{X}_{(t)}+\frac{1}{6}\left(k_{1}+2 k_{2}+2 k_{3}+k_{4}\right)
$$

によって求められる。 ただし，

$$
\begin{aligned}
& k_{1}=\mathbf{U}\left(\mathbf{X}_{(t), t) \Delta t}\right. \\
& k_{2}=\mathbf{U}\left(\mathbf{X}_{(t)}+\frac{1}{2} k_{1}, t+\frac{1}{2} \Delta t\right) \Delta t \\
& k_{3}=\mathbf{U}\left(\mathbf{X}_{(t)}+\frac{1}{2} k_{2}, t+\frac{1}{2} \Delta t\right) \Delta t \\
& k_{4}=\mathbf{U}\left(\mathbf{X}_{(t)}+k_{3}, t+\Delta t\right) \Delta t
\end{aligned}
$$

$\Delta t$ をむやみに大きくとると $X(t+\Delta t)$ が $X(t) 0)$ 存在す る格子の外に出てしまって、流速の補間誤差が大きく なるので、計算領域内の最大流速場 $(20 \mathrm{~cm} / \mathrm{s})$ でも格 子内 $(40 \mathrm{~m})$ にとどまる時間刻み $(3 \mathrm{~min})$ で粒子追跡を 行った。

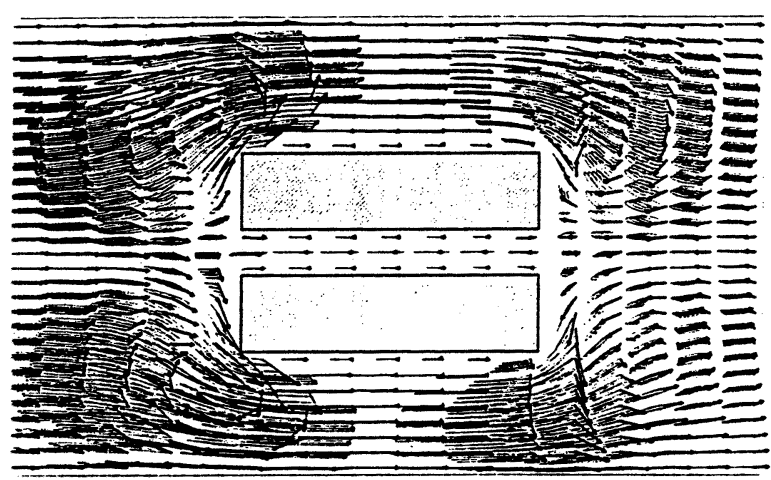

(1) 上層

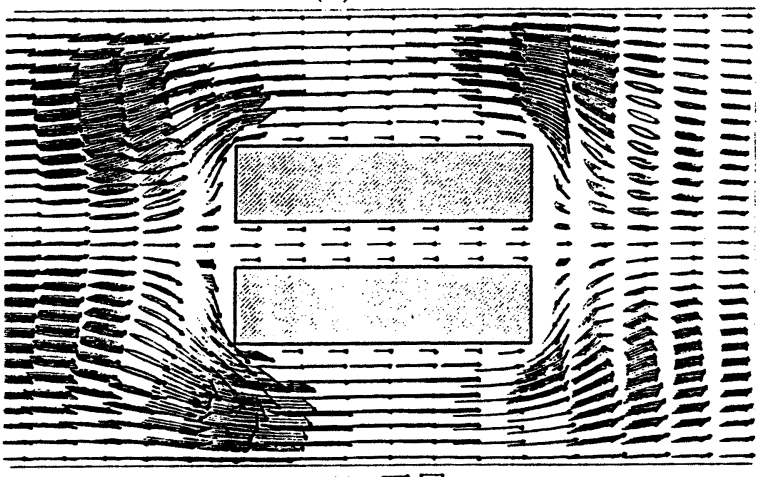

(2) 下層

図-2 15 分間隔の粒子追跡図

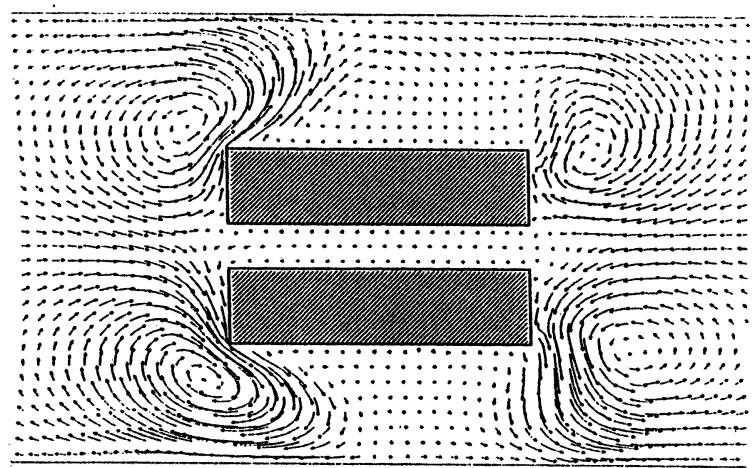

(1) 上層

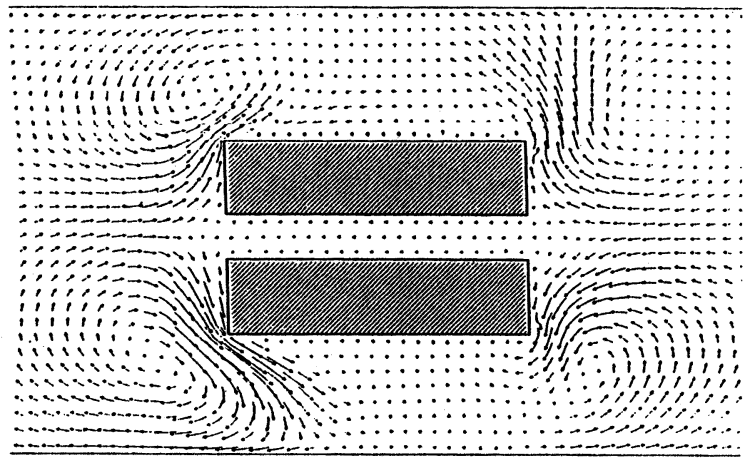

（2）下層

図-3 1 周期間隔の粒子追跡図 


\section{3. 長水路型の数値シミュレーション}

\section{1 粒子追跡結果}

静止状態から流速場を計算した結果、第 2 周期目でほぼ安定し、第 5 周期目にはほとんど定常状態に達して いることが確認できたので、粒子追跡には第 6 周期目の流速場を繰り返し用いた。

図- 2 は、4 周期間に互って粒子追跡をしたもので、矢印は、各粒子の最初に存在した位置と 4 周期後の位置 を結んだものである。また、図-3 3 は 4 周期間に互る粒子の運動を 1 周期ごとにプロットして、残差流だけを表 現している。上下層ともに艮方形の島を囲むように残差流の渦が 4 つ形成されている。時計回りの渦では上層で は渦の中心に粒子が収束し、下層では渦の中心から粒子が分散している。逆に反時計回りの渦については上層で 分散、下層で収束をしている。また上下の収束渦と分散渦の中心の位置が若干ずれていて、渦の中心が水深によ って移動している。長水路内では潮流による往復流があるにもかかわらず、粒子は 4 周期後には元の位置からわ ずかに西側に移動しているだけである。

\section{2 鉛直流速分布}

第 6 周期目の流速場における上層と下層の境界面における 1 周期平均鉛直流速の分布を図- 4 に示寸。実線は 鉛直上向きの流速、破線は鉛直下向きの流速を表している。長水路内では鉛直方向の流速は存在せず上層と下層 の間での海水交換はほとんど行われていない。長水路外 の海域では島の角に強い上昇スポットが存在し、時計回 りの水平残差流の渦が存在したところでは下降流域が見 られる。逆に反時計回りの水平残差流の渦が存在したと ころでは島角の上昇スポットと渦に伴う上昇域とが合体 して強くて大きな上型域が形成されている。ここで問題 とされる上昇スポットの生成メカニズムについては，觕 部では順圧勾配力と遠心力の釣り合いによって海水は流 れているが，海底では摩擦によって遠心力が弱められバ ランスがくずれて，摩擦層内の海水は角部へ押され，上 昇流が形成されると考えられる。4

\section{3 海水交換特性}

3.1 で見られるように、長水路内では潮流が発達して いるのにも関わらず残差流は微弱で海水交換はそれほど 期待できない。逆に島角付近ではそれ程潮流は目立たな いにも関わらず地形性渦流や水平残差流が発達して海水 交換が良いことがうかがえる。潮流場における海水交換 は、これらの流れに依存するのであって潮流の強さに単 純に依存していないことが特徴的である。そこで最も污 染度の高いと思われる水路中央部での汫留時間を以下の ように求めてみた。粒子追跡による 4 周期間での粒子移 動距雒から粒子の平均移動速度を出して、粒子が外海に 流出するまでにかかる時間を計算すると、上層では中央 の㴋留時間が 59.3(日)に対し、両側の粒子が 172.7 (日)と 非常に長く、下層では中央の粒子が 90.5(日)で両側の粒 子が 271.6(日)となり、下層の方が上層と比べてかなり海 水交換が悪いことがわかる。

\section{4 .港湾型の数値シミュレーション}

\section{1 粒子追跡結果}

次に, 港湾型地形について基本型として矩形の掘り込 み湾型の TYPE1, さらにこの基本型の湾口両端部を外 海に突出させた TYPE2 の 2 種類について海水交換特性 を調べた。UENO $5^{5)}$ が湾口の先端部に出っ張りを付 けることで海水交換が良くなることを報告しているので、 TYPE2 はその原理を究明するために設けたモデルであ

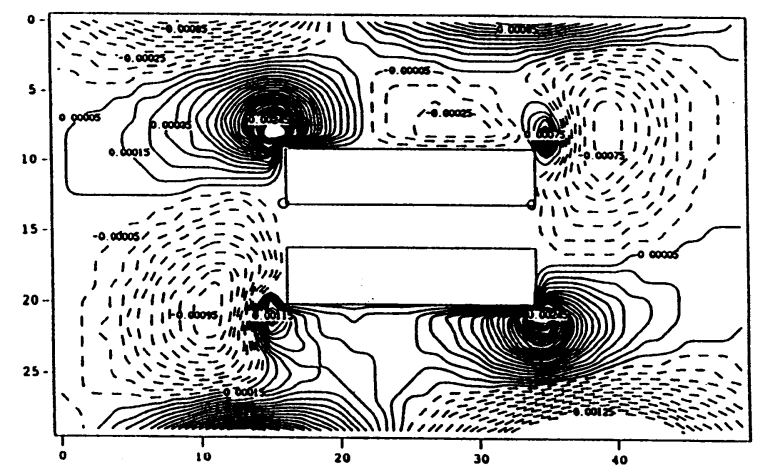

図-41 周期平均鉛直流速分布

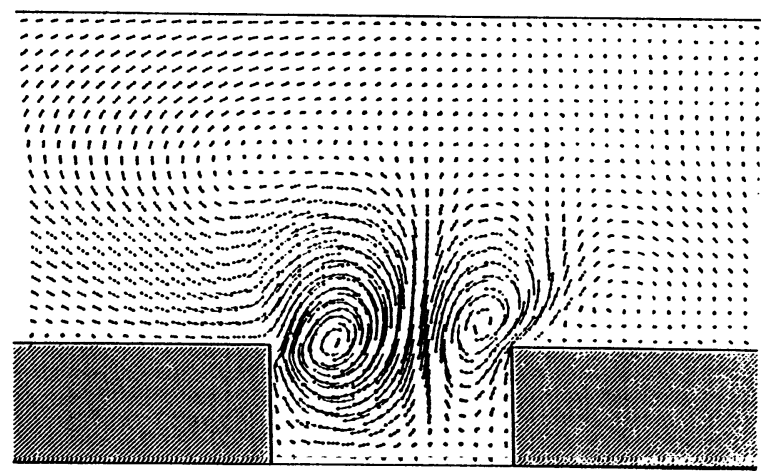

（1）上層

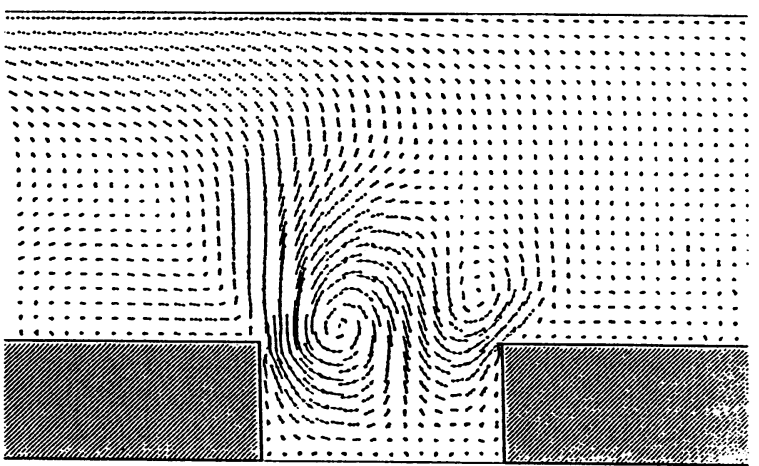

（2）下層

図 -5 TYPE1 の 1 周期間隔の粒子追跡図 (12 周期間) 
る。長水路型のときと同様に港湾型においても流速場は第 5 周期目あたりで定常状態に達したので、第 6 周期目の流 速場を繰り返し用いて粒子追跡を行っている。

TYPE1、TYPE2 の 12 周期間 ( 6 日間)に互る粒子追跡 結果を 1 周期ごとにプロットして残差流の分布を求めた のが図-5、6である。両者ともに湾口中心付近から湾内 に流入してきた粒子が渦を巻くような形で東西に別れて湾 外に流出している様子が現れている。西側の渦の中心は湾 内と外海の境界線上にあり、東の渦の中心はそれより少し 沖側に存在する。この 2 つの渦が東西に対象な形ではなく 西側の渦が東側に比べて大きくなっているのは、境界条件 の与え方が西端で開境界であるに対して東端は閉じている という非対称条件によるためと思われる。また上層と下層 の渦を比べると下層の渦は少し小さ目で、渦の中心の位置 も若下ずれており水梁によって渦の中心位置が移動してい る。西側の渦では、周辺海域の粒子が渦の中心に収束し、

下層では逆に外海に粒子を分散しており、東側の渦では上 層で粒子を外海に分散し、下層で収束している様子が見ら れる。

TYPE2 は港湾内の海水の流入出形態は TYPE1 と同様 であるが，湾口部に発生した残差渦が一回り大きくなって おり、渦の中心位置も TYPE1 と比べて若干沖に移動して いる。

\section{2 鉛直流速分布}

第 6 周期目の流速場における上層と下層の境界面におけ る鉛直流速の 1 周期平均した分布が図- 7 である。TYPE 1 、 TYPE2 ともに港口の角付近に強い上昇スポットが存在し た。中央やや西側よりの強い時計回りの渦に対応して下降 流域がある。隣り合う東側の弱い反時計回りの渦に対応寸 る上昇流域は角の上昇スポットと合侀して西側の下降流域 に匹敵する規模である。このように、陸地の角に水平渦を 伴わない强い上昇スボットが発生することと、その付近に もっと大きいスケールで残差流渦が存在して時計回りの渦 は下降流を、反時計回りの渦は上昇流を伴い、後者は上昇 スポットと合併してより広範囲の上昇流域を作り出すこと は层水路型地形においても見られる特徵である。

次に上層と下層間での海水交換時間について調べる。最 大鈆直流速が分布している海域で 2 層間を粒子が移動する のにかかる時間を求めることにする。鉛直方向の平均流速 は境界面での流速の $1 / 2$ で近似して、最大鉛直流速 $5.0 \times$ $10^{-4}\left(\mathrm{~cm} \cdot \mathrm{s}^{-1}\right)$ の半分の流速 $2.5 \times 10^{-4}\left(\mathrm{~cm} \cdot \mathrm{s}^{-1}\right)$ で 2 層間 $(10 \mathrm{~m})$ の移動時間を求めたところ約 46.3 (日) かか ることになる。

TYPE1 と TYPE2 の鉛直流速分布を比較すると分布形態は 同様であるが、TYPE2 では平均鉛直流速が $5.0 \times 10^{-4}(\mathrm{~cm}$. $\left.\mathrm{s}^{-1}\right)$ の分布範囲が TYPE1 と比べてかなり大きくなってい ることがわかる。また全体的な鉛直流速分布も広がってい ることから, TYPE2 は TYPE1 と比べて上下層間の海水 のやり取りが盛んになっていることがわかる。

\section{3 海水交換特性}

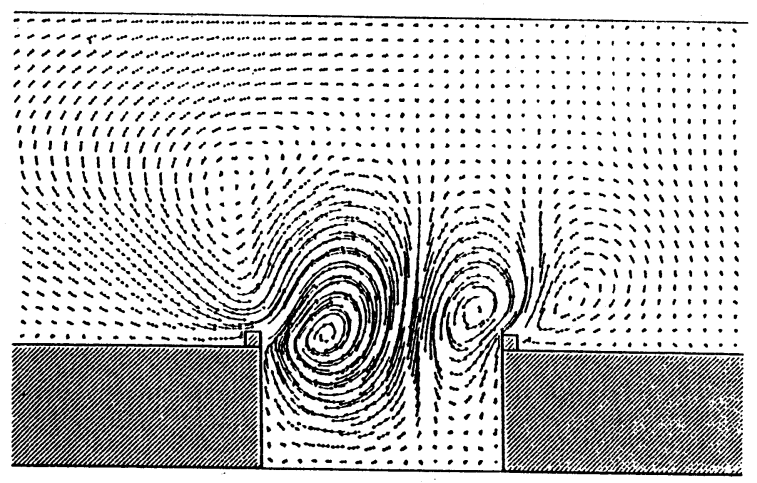

（1）上層

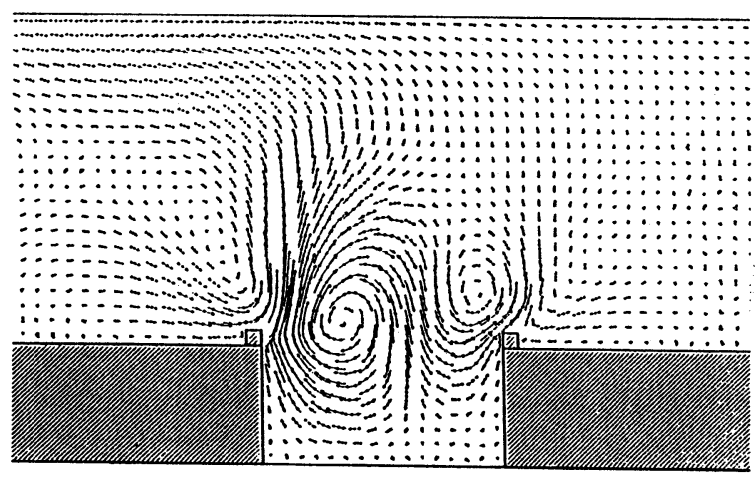

（2）下層

図-6 TYPE 2 の 1 周期間隔の粒子追跡図 (12 周期間)

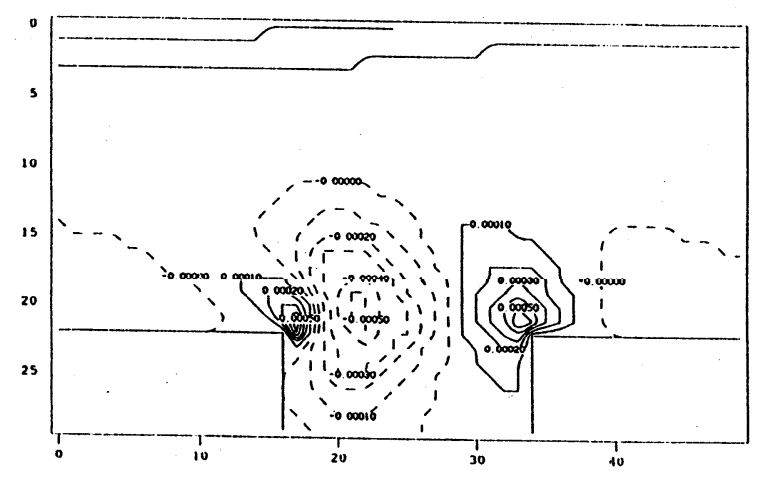

(1) TYPE1

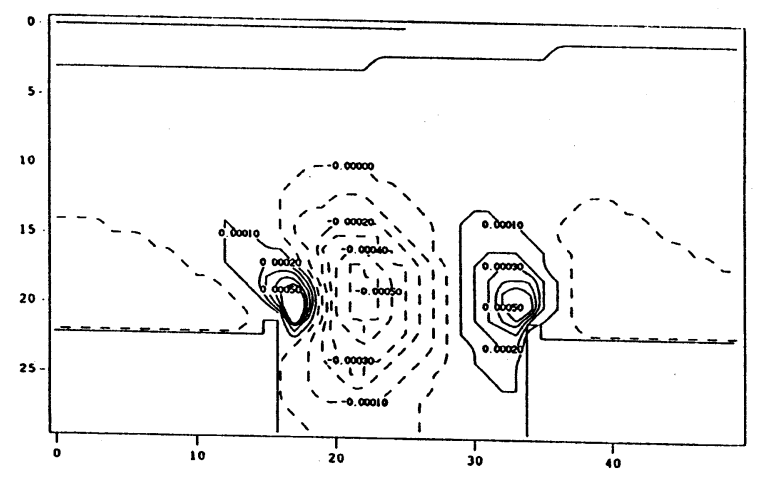

(2) TYPE2

図-7 1 周期平均鉛直流速 
港湾内での一般的な海水交換は、水平循還流が湾内を 循環する間に潮流とそれに伴う渦流や乱流によって内湾 水の一部を取り込んで外海に運び出すとともに、それと 等量の外海水を湾内に引き入れることで行われている。 湾口の地形を変えた 2 種類の港湾について粒子追跡図よ り 4 周期 ( 2 日)、 8 周期 ( 4 日)、 12 周期 ( 6 日)後の上層、 下層の湾内での流出粒子数と流入粒子数を表- 1 , 表- 2 にまとめている。

それによると上層では TYPE1、TYPE2 ともに流入粒 子数が流出粒子数を上回っており、下層においては流出 粒子数が流入粒子数を上回っている。これは上層で湾内 一海水が流入して、下層では外海へ流出していることを 表わしている。そこで上層と下層の雨層での総流出粒子 数と総流入粒子数を比べてみるとほぼ同数になってお り、上層と下層で湾内の粒子数がほぼ保存されている。 このことは質量保存式から当然あるべき結果であるが、 1 格子に 1 個の粗い粒子追跡で充分海水の流動を定量的 に議論できることを示している。このことから湾内の海 水交換率を評価するには、上層と下層での流入粒子数和 と流出粒子数和の平均值が湾内の総粒子数に対する割合
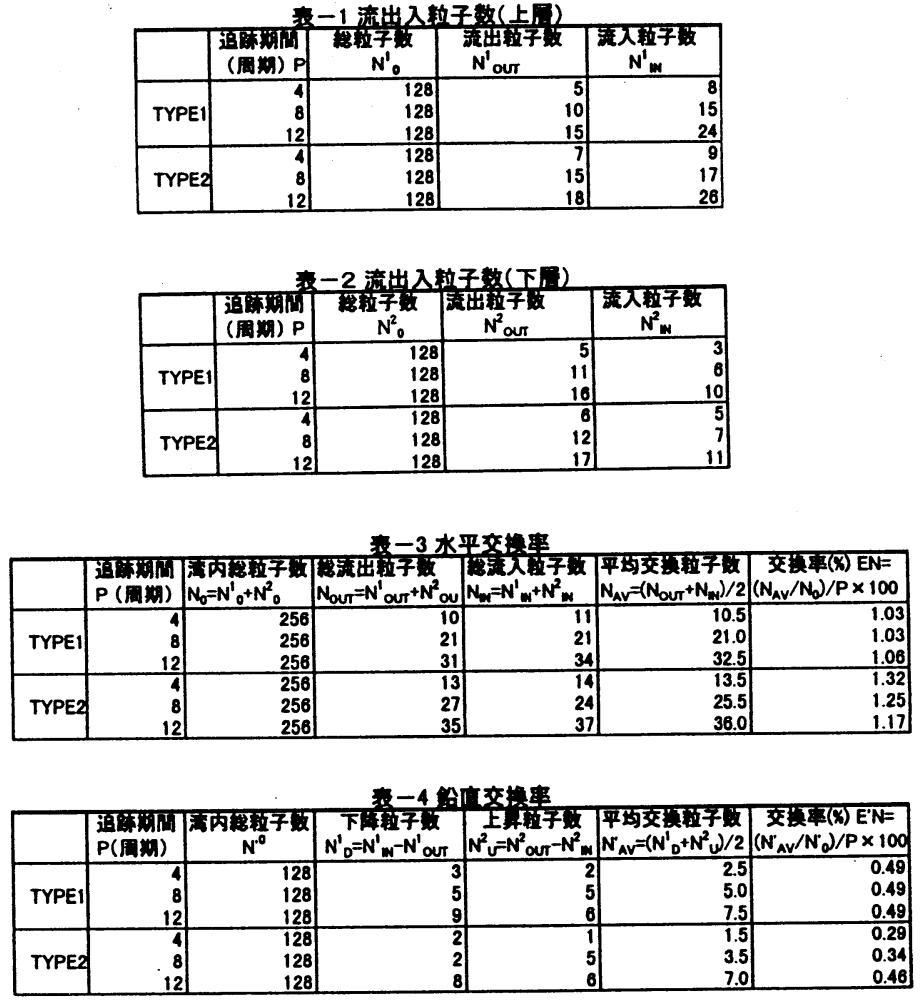
で表すこととして、1 周期あたりの海水交換率を求めたものが表- 3 である。

TYPE 1 を基準にして考えると、湾口両端部が外海に觉出している TYPE2では交換率が上がっている。外海 の卓越潮流方向に垂直に伸びている港口突出部分が潮流の分離を促進し、湾口付近における残差渦の強さが增加 したためと考えられる。このことから海水交換を促進させるには、その海域で卓越する流れを妨げるような方向 に突堤を伸ばしてやることが有効であることがわかるが、むやみに伸ばしてもいいと言う訳でもない。TYPE2 の突堤をさらに伸ばしたら、残差渦自体の威力は增大したものの交換率は低下した（図省略）。これは突堤部延 長によって残差渦の中心が沖の方に移動したため、渦は增大してもその効果が湾奥まで伝わらず、湾奥を含む海 水交換が低下したためである。このことから、大きな残差渦の中心が湾口境界線上にのるように作れば海水交換 率は良くなると思われる。

上層と下層とも流入粒子数と流出粒子数とで差が生じていたが、湾内の海水量の保存からこれらの差の分が鉛 直方向の海水のやり取りを表わしていると思われる。この考えに基づき湾内の鉛直方向の海水交換率を求めたの が表-4である。その大きさは湾口を通しての水平方向の交換率の半分近くになっている。鉛直流速は一部を除 くと微弱であるのに鉛直方向の海水交換がこのように大きいのは、水平方向の交換が湾口断面（幅 $640 \mathrm{~m}$ 哚さ $20 \mathrm{~m}$ ）を通してなされるのに対し、鉛直方向の交換は港湾全域（幅 $640 \mathrm{~m}$ 、奥行き $320 \mathrm{~m}$ ）で行われるためであ る。また水平方向の海水交換では TYPE 2 が TYPE 1 に勝っていたが、鉛直方向の海水交換においては、TYPE 1 の方が TYPE 2 より大きい。 4.2 で述べたように、対象領域 全体では TYPE 2 の方が鉛直混合も盛んであるが、水平渦が沖 に少し移動したため、湾内に限って交換量を求めると TYPE 1 のほうが勝るのである。

次に、最初に湾内に存在した粒子の湾内残存率の時間経過 を図-8に示す。ここでは $1 / 48$ 周期(15 分)間隔で湾内における 残存率をプロットして、各潮時における残存率の変化を示して いる。それによると、最初の 1 周期後の残存率は 1.0 で、湾内 水は 1 周期後には寸べて湾内に戻って、湾内の海水交換がなさ れていないことになるが、これは 1 格子 1 個の粗い粒子配分 のためである。しかし、その後は 1 周期経つごとに残存率は徐々 に下がっており、湾内での海水交換が進んでいることを表して いる。1からこの残存率を引いた值は、先に粒子追跡図より流 出粒子数だけを数えて求めた交換率に相当し、この折れ線の傾 きの絶対值を海水交換の進行速度と考えることができる。
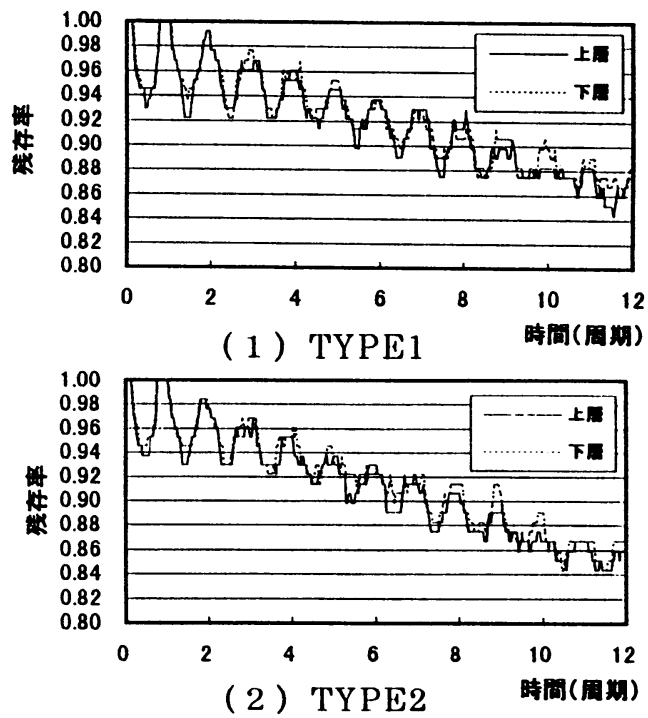

図-8 湾内残存率図 
以上の結果は港湾全体の海水交換特性を表すもの であるが、実際に問題になるのは港湾内の局部的な水 質污染である。そこで粒子追跡を開始して 12 周期後 に各格子内に存在する粒子がそれまで湾内に滞留して いた時間を求め、格子内で平均を取り、12 周期間に 対する割合を求めたのが図-9 である。これは港湾内 の停沸水の分布を表している。色が濃いところほど湾 内での滞留時間が長い。上層では、湾口中央部に湾内 滞留時間が短い粒子が分布しており、この辺りでは水 質の良い海水が存在していることがわかる。下層では、 湾口中央部から湾奥や西湾岸の方にかけて湾内滞留時 間の短い粒子が分布している。これは湾口上層中央部 から沈降しつつ湾内に流入した粒子が湾奥方向に分散 しているものと思われる。

\section{5.まとめ}

艮水路内と港湾内における海水交換特性を 2 層モデ ルによる湖流計算と粒子追跡を用いて調べ、以下の結 論を得た。

「長水路型地形」

・長水路内では潮流がある程度発達しているにもかか わらず、海水はほとんど同じ所を往復運動し、わず
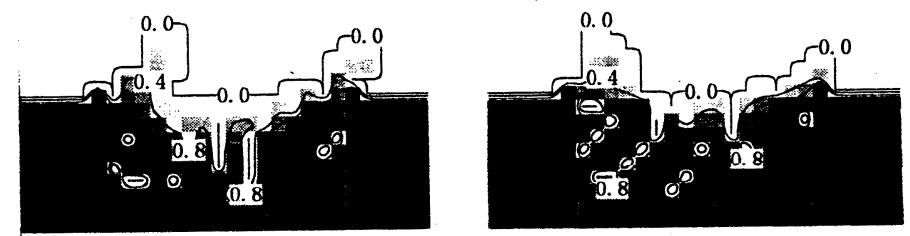

(2)TYPE2

図-9 湾内滞留率分布 かに西方移動しているだけで、長水路内での海水の滞留時間は非常に長くなっている。

・長水路内での鉛直流速分布は見られず鉛直方向の海水交換もほとんどない。

・島角付近の上昇域とその外側の残差流渦に伴う上昇下降流域とが複合して、島の回りに鉛直循環を含む活発な 残差流循環が形成されている。

「港湾型地形」

・湾内全体としての海水交換は上層で湾内に流入した海水の一部が下層で湾外に流出している。

・湾口中央部から湾奥にかけて比較的水質の良い海水が存在している。

・潮流の流れに逆らうような地形によって湾口渦は增大し湾内での海水交換を促進している。

・湾内の海水交換率は湾口渦の大きさとその中心の位置に依存する。

・上層と下層の流入粒子数と流出粒子数の差から鉛直方向の海水交換 が予想以上に活発であると考えられる。

鉛直流速は水平流速に比べて非常に小さいため鉛直方向の海水交換㹥落としがちであるが、鉛直方向の交 換は非常に広い面積で行われているため、その速度が微少であっても無視寸ることは出来ない。

おわりに本研究を進めるにあたり、潮流計算と粒子追跡のプログラム提供と指導をいただいた京都大学理学 部海洋研究室の今里哲久教授、淡路敏之教授および秋友和典助教授に感謝の意を述べる次第である。

参考文献

(1) 今里哲久,淡路敏之 (1982):明石・鳴門海峡を通しての海水交換の数值実験.沿岸海洋研究ノート,第 20 巻,第 1 号,pp.19 to 32 .

(2) 淡路敏之,今里哲久,佐藤敏 (1985): 沿岸潮汐の数值実験について沿岸海洋研究ノート,第 23 巻,第 1 号, pp.35 to 47.

(3) Norihisa IMASATO, Toshiyuki AWAJI, Hideaki KUNISHI (1980):Tidal Exchange through Naruto, Akashi and Kitan Straits. Journal of the Oceanographical Society of Japan,Vol.36,pp.151 to 162.

(4) Norihisa IMASATO, Shinzou FUJIO, Qian ZHANG, Toshiyuki AWAJI, Kazunori AKITOMO (1997): Three-Dimensional Numerical Experiments on Tidal Exchange through a Narrow Strait in a Homogeneous and a Stratified Sea.Journal of Oceanography,Vol.50,pp.119 to 139.

(5) Seizo UENO, Hideo OHTANI, Fumio KANEKO (1997): Problems and Improvement Methods of Water Quality in Eutrophicated seas in Japan, pp.237 to 246. 